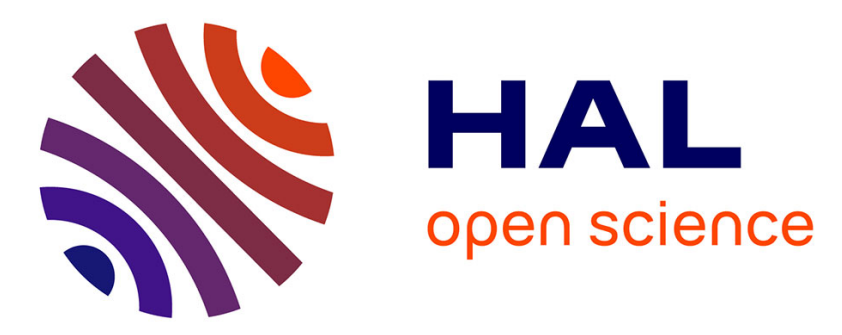

\title{
Nitration of cathepsin D enhances its proteolytic activity during mammary gland remodeling after lactation
}

Rosa Zaragozá, Luis Torres, Concha García, Pilar Eroles, Fernando Corrales, Ana Bosch, Ana Lluch, Elena R. García-Trevijano, Juan R. Viña

\section{- To cite this version:}

Rosa Zaragozá, Luis Torres, Concha García, Pilar Eroles, Fernando Corrales, et al.. Nitration of cathepsin D enhances its proteolytic activity during mammary gland remodeling after lactation. Biochemical Journal, 2009, 419 (2), pp.279-288. 10.1042/BJ20081746 . hal-00479092

\section{HAL Id: hal-00479092 https://hal.science/hal-00479092}

Submitted on 30 Apr 2010

HAL is a multi-disciplinary open access archive for the deposit and dissemination of scientific research documents, whether they are published or not. The documents may come from teaching and research institutions in France or abroad, or from public or private research centers.
L'archive ouverte pluridisciplinaire HAL, est destinée au dépôt et à la diffusion de documents scientifiques de niveau recherche, publiés ou non, émanant des établissements d'enseignement et de recherche français ou étrangers, des laboratoires publics ou privés. 
Nitration of cathepsin D enhances its proteolytic activity during mammary gland remodeling after lactation

Rosa ZARAGOZÁ*, Luis TORRES*, Concha GARCÍA*, Pilar EROLES ${ }^{\dagger}$, Fernando CORRALES $^{\ddagger}$, Ana BOSCH ${ }^{\dagger}$, Ana LLUCH ${ }^{\dagger}$, Elena R. GARCÍA-TREVIJANO ${ }^{*}$ and Juan R. VIÑA*

*Departamento de Bioquímica y Biología Molecular, `Servicio de Oncología Hospital Clínico/Fundación de Investigación. Facultad de Medicina. Universidad de Valencia, E-46010 Valencia. ${ }^{\ddagger}$ División de Hepatología y Terapia Génica, CIMA. Universidad de Navarra. E31008 Pamplona. SPAIN.

Short Title: Cathepsin D nitration and activation during weaning

Address correspondence to:

Juan R.Viña,

Departamento de Bioquímica y Biología Molecular,

Facultad de Medicina, Universidad de Valencia, Avda. Blasco Ibáñez 15, E-46010 Valencia, SPAIN. Tel. (+34)96-3864187; Fax. (+34)96-3864001;

E-Mail: Juan.R.Vina@uv.es 


\section{SYNOPSIS}

Proteomic studies in the mammary gland of control lactating and weaned rats have shown that there is an increased pattern of nitrated proteins during weaning when compared to controls. Here we report the novel finding that cathepsin $D$ is nitrated during weaning. The expression and protein levels of this enzyme are increased after 8 hours of litter removal and this up-regulation declines 5 days after weaning. However, there is a marked delay in cathepsin $D$ activity since it does not increase until 2 days postweaning and remains high thereafter. In order to find out whether nitration of cathepsin $D$ regulates its activity, iNOS -/- mice were used. The expression and protein levels of this enzyme were similar to wild type animals but the proteolytic activity was significantly reduced during weaning in knock-out when compared to wild type mice. In vitro treatment of recombinant human cathepsin $D$ or lactating mammary gland homogenates with relatively low concentrations of peroxynitrite enhances the nitration as well as specific activity of this enzyme. Using mass spectrometry it has been shown that residue $\mathrm{Tyr}^{168}$ was nitrated. All these results show that protein nitration during weaning might be a signaling pathway involved in mammary gland remodeling.

Keywords: mammary gland involution, nitrotyrosine, post-translational modification, cathepsin D activity

Abbreviations footnote: MMP, matrix metalloproteinase; ECM, extracellular matrix; iNOS, inducible nitric oxide synthase; ONOO-, peroxynitrite; $\mathrm{CD}$, cathepsin D; WT, wild-type; Psp. A, pepstatin A; NO, nitric oxide.

\section{INTRODUCTION}

The mammary gland is a complex, highly dynamic organ that has evolved to provide nutrition and immunological protection for the offspring of mammals [1]. The mammary gland undergoes cycles of proliferation, differentiation, and apoptosis with each successive pregnancy/lactation cycle. During mammary gland involution after natural weaning or litter removal, the gland is properly remodeled to a virgin-like state through a process involving apoptosis and tissue remodeling in which the epithelial compartment of the gland regresses and the adipocytes redifferenciate, refilling the adipose compartment. Under conditions of forced weaning, this process is separated into two phases [2, 3]; the first phase is characterized by apoptosis of the secretory alveolar epithelium without major changes in gland architecture. This primary apoptotic process is reversible if suckling is resumed and it is mainly controlled by $\mathrm{p} 53$. In the second phase, apoptosis is accompanied by activation of matrix metalloproteinases (MMP) that are involved in the degradation of extracellular matrix (ECM) and alveolar basement membrane. This stage is irreversible and p53-independent. This second phase is also associated with redifferentiation of the adipocytes.

Lactating mammary gland involution is initiated upon cessation of suckling. A number of mammary-derived signals are currently considered possible inducers of mammary epithelial cell apoptosis [2, 3]. Indeed, the essential signaling pathways that initiate involution have been extensively studied by genetic and microarray approaches $[4,5,6]$. Using genetically modified mice, many different factors that either promote or delay involution have been identified. Among the promoters, Bax, STAT3 [3, 7], TNF- $\alpha$ [8], and retinoids [9, 10] are found. Interestingly, the NF- $\mathrm{BB}$ pathway is activated at the early events that trigger apoptosis [3]; in fact, activation of NF- $\kappa \mathrm{B}$ is one of the most rapid transcription factor responses in the involution of the mammary gland, with detectable DNA binding within $2 \mathrm{~h}$ following litter 
removal [11]. Downstream targets of this pathway are up-regulated, ensuring the transition to the second phase of involution. In previous studies, we have demonstrated an induction of iNOS gene expression (NOS-2, inducible nitric oxide synthase), regulated by NF- $\kappa \mathrm{B}$, during weaning, resulting in an increase in nitric oxide (NO) levels and, subsequently, increased protein nitration [6].

Nitration is a post-translational modification of tyrosine residues of proteins mediated by peroxynitrite $\left(\mathrm{ONOO}^{-}\right)$. Nitration of tyrosine or tyrosyl groups of a protein modulates protein function and is involved in signal transduction pathways, which lead to an alteration of cellular metabolism and functions. In particular, $\mathrm{ONOO}^{-}$-induced protein oxidation often leads to a loss of protein activity [12, 13], seldom to activation [14, 15, 16]. Because of its recognized significance, there is an increasing interest to identify nitrated proteins in order to gain a better understanding of their involvement in different biological processes, as is the case for mammary gland remodeling. In the present study, using mass-spectrometry-based proteomic technology, the pattern of nitrated proteins during weaning was analyzed and compared to control lactating mammary glands. We have identified cathepsin D (CD) (EC 3.4.23.5) within the nitrated proteins found after weaning, and for the first time we describe this post-translational modification on this enzyme.

$\mathrm{CD}$ is a major aspartic proteinase of endosomes and lysosomes and it is a member of the pepsin family of proteinases [17]. It is involved in the turnover of cellular proteins as well as in the selective processing of MHC II antigens, hormones, and growth factors, in the range of $\mathrm{pH}$ 2.8-5.0. Gene knockout studies have demonstrated that cathepsin D-deficient mice die prematurely from massive destruction of lymphoid organs and progressive atrophy of the intestinal mucosa, suggesting essential functions of CD in tissue homeostasis [18]. CD is synthesized as an inactive $52 \mathrm{KDa}$ pre-pro-enzyme that undergoes sequential proteolytic cleavages to produce the mature form. In lysosomes, the removal of 44 amino acids from the amino terminus yields an active $48 \mathrm{KDa}$ single-chain molecule. This single chain form is then cleaved by auto-processing and, mainly, by cysteine proteinases into a mature two-chain enzyme consisting of a light $14 \mathrm{KDa}$ amino-terminal domain and a heavy $34 \mathrm{KDa}$ carboxylterminal domain [19]. CD is increased during weaning, playing a key role in protein degradation during mammary gland apoptosis; indeed, CD is known to be involved in the mitochondrial caspase-dependent intrinsic pathway of cell death [20]. Despite the relevance of this proteinase in physiological and pathological events, few data exist on the factors that modulate its secretion, activity, and extracellular function in lactating mammary tissues. Recently it has been demonstrated that prolactin controls the processing and polarized secretion of CD in this tissue [21]. On the other hand, interferon- $\gamma$ activates Stat- 1 resulting in decreased vacuolar $\mathrm{pH}$ which greatly affects $\mathrm{CD}$ processing and secretion [22]. In regard to $\mathrm{CD}$ activation, here we report the novel finding that $\mathrm{CD}$ is nitrated during weaning; $\mathrm{Tyr}^{168}$ is identified as the modified residue. Moreover, it is noteworthy that in vivo and in vitro nitration of CD enhances its proteolytic activity. All these results highlight the importance of protein nitration as part of the physiological events that take place at the end of lactation, when the mammary gland is prepared for the next pregnancy/lactation cycle.

\section{EXPERIMENTAL}

Animals and tissue extraction

Pregnant Wistar rats (Harlan), wild-type (WT) control mice and iNOS -/- mice (Taconic, Ejby, Denmark) were used. Mice were C57BL/6 and the genotype of the iNOS -/- strain was verified by PCR, using DNA prepared from tail samples taken at the end of the experiments. Animals were kept in individual cages in a controlled environment (12h light/ 12h dark cycle) and they received water and food ad libitum. They were cared for and handled in conformance with the $\mathrm{NIH}$ guidelines and the Guiding Principles for Research Involving Animals and Humans 
approved by the Council of The American Physiological Society. The Research Committee of the School of Medicine (University of Valencia, Valencia, Spain) approved the study protocol. Following parturition, the litters were maintained with at least 10 pups in rats and 7 pups in the case of mice.

At the peak of lactation (days 12-14), the rats were divided into different groups: Control lactating rats $(\mathrm{n}=8)$ or weaned rats from which pups were removed 12 days after delivery to initiate involution. Mammary tissue samples were collected at the indicated times after weaning (at least three rats for each condition were used). In the case of mice, the groups were as follows: Control mice at the peak of lactation (days 9-11) or weaned animals from which the litter was removed 6, 24, 48 and 72 hours before sacrifice.

The animals were anesthetized with sodium pentobarbital $(60 \mathrm{mg} / \mathrm{kg}$ body wt. in $0.9 \% \mathrm{NaCl}$ i.p.; Abbott Laboratories, S.A.) and killed immediately after removing the inguinal mammary glands that were snap frozen in liquid nitrogen and stored at $-80^{\circ} \mathrm{C}$ for further analysis.

\section{Antibodies}

Depending on the species and the forms of CD to be detected, different CD antibodies were used in the Western blots. A rabbit polyclonal anti-human CD antiserum (Santa Cruz Biotech. SC-10725, Santa Cruz, CA, USA) was used to determine the expression of pro-CD and mature single chain forms of $\mathrm{CD}$ in rats and mice. This antibody was also used for $\mathrm{CD}$ immunoprecipitation. The Santa Cruz antibody is made to an N-terminal peptide of the mature single chain and should thus be able to detect the pro form, the single chain form and the light chain of double chain form, which includes the N-terminus. Nonetheless, we could only detect the pro and the mature single chain forms. For this reason, other anti-CD antibodies were used: a rat monoclonal anti-mouse CD antiserum (Clone: 204712) from R\&D Systems (Minneapolis, USA) was used in blots from mice homogenates to visualize the mature double chain forms of $\mathrm{CD}$, both the heavy and light chains. Finally, a mouse monoclonal anti-human CD antibody (Clone: BC011) from Calbiochem (Schwalbach, Germany) was used to determine the expression of recombinant $C D$ from human liver and in the immunoblots performed after immunoprecipitation of CD. To corroborate "in vitro" nitration with peroxynitrite, a mouse monoclonal NO-tyrosine antibody (Clone 1A6) was used (Upstate, Lake Placid, NY, USA).

\section{Immunoblotting}

Protein expression was evaluated by a standard immunoblotting procedure. Mammary gland tissues were homogenated in a buffer containing detergents and protease inhibitors as described previously [23]. 20 $\mu$ g of whole extract proteins, quantified by the Bradford assay, were denatured with Laemmli sample buffer, separated by electrophoresis on a $12 \%$ polyacrylamide gel (Bio-Rad, Munich, Germany), and then electroblotted onto a nitrocellulose membrane (Protran $®$, Whatman, Kent, UK). After addition of the corresponding primary antibody, immunocomplexes were revealed by using a peroxidase-conjugated secondary antibody (Santa Cruz Biotech.), as appropriate, and subsequent peroxidase-induced chemiluminiscence reaction (ECL, Amersham Pharmacia Biotech., Buckinghamshire, UK).

\section{Immunoprecipitation}

Tissue lysates obtained from lactating and weaned mammary glands were precleared with protein A and G-Sepharose (50:50 v/v) (Amersham Pharmacia Biotech) for $1 \mathrm{~h}$ at $4^{\circ} \mathrm{C}$ and centrifuged for 5 min. The supernatant was incubated first with the anti-cathepsin D antibody from Santa Cruz Biotech overnight at $4^{\circ} \mathrm{C}$, and then with protein A and G- Sepharose (50:50 $\mathrm{v} / \mathrm{v}$ ) for $4 \mathrm{~h}$ at $4^{\circ} \mathrm{C}$ on a rotating device. Pellets were collected by centrifugation at $12000 \mathrm{rpm}$ for $1 \mathrm{~min}, 4^{\circ} \mathrm{C}$. The supernatants were discarded, and each pellet was subsequently washed 
three times with Tris- $\mathrm{HCl} \mathrm{pH}$ 8.0. After washing the sepharose, the immunocomplexes were eluted by boiling in the SDS-gel sample buffer for $5 \mathrm{~min}$ and then subjected to SDS-PAGE immunoblot as described previously. Representative results of three separate experiments are shown.

\section{Pepstatin A-affinity purification of $C D$}

Homogenates from weaned mammary gland (500 $\mu$ g of whole extract proteins) were incubated for $15 \mathrm{~h}$ at $4^{\circ} \mathrm{C}$ with pepstatin A-agarose coated beads (Sigma) in $20 \mathrm{mM}$ citrate phosphate buffer $\mathrm{pH}$ 7.0, according to Follo et al. [24].Then, the mixture was centrifuged at 20000g for 5 min. and the pellet was washed with $20 \mathrm{mM}$ citrate phosphate buffer $\mathrm{pH}$ 7.0. Finally the pellet was re-suspended and denatured in $30 \mu \mathrm{l}$ of sample loading buffer prior to western blotting analysis.

Two-Dimensional Electrophoresis

Mammary gland tissue from each condition was homogenized in rehidratation buffer from BioRad (8M Urea, 2\% CHAPS, 50mM DTT, 0.2\% Bio-Lyte ${ }^{\circledR}$ 3/10 ampholyte, $0.001 \%$ Bromophenol blue). After cleaning up the samples with ReadyPrep 2-D Cleanup kit (BioRad), $500 \mu \mathrm{g}$ of tissue lysates were loaded on precast immobilized $\mathrm{pH}$ gradients (IPG) gel strips $\mathrm{pH}$ 5-8 (BioRad) and subjected to IEF two-dimensional (2D) PAGE. The isoelectrofocusing conditions were those recommended by the manufacturer for the type of strip used. Second dimension gels contained 8\% acrylamide. Simultaneously, proteins were resolved by 2D PAGE and then electroforetically transferred to nitrocellulose membranes (Protran ${ }^{\circledR}$, Whatman) or visualized using silver or coomassie stainings. Membranes were probed with a 1:1000 dilution of anti-nitrotyrosine antibody (Upstate) as described above. Spots corresponding to nitrated proteins were excised manually from coomassie-stained gels and identified by mass spectrometry.

\section{Protein identification by Mass Spectrometry}

Protein preparation and tryptic digestion. Protein samples corresponding to weaned mammary gland lysates recovered from 2D gels, were precipitated with 20\% TCA on ice and, after centrifugation, the pellet was washed with cold acetone. The same procedure was performed in the case of human CD $(25 \mu \mathrm{g})$ treated with $20 \mu \mathrm{M}$ peroxynitrite or with $1.2 \mathrm{~N} \mathrm{NaOH}$, in order to identify the nitration site of the enzyme. Precipitated proteins were resuspended in $25 \mathrm{mM}$ ammonium bicarbonate and digested with $12.5 \mathrm{ng} / \mu \mathrm{l}$ trypsin for $12 \mathrm{~h}$ at $37^{\circ} \mathrm{C}$.

LC-ESI-MS/MS analysis. MS/MS analysis was performed as previously described [25]. Microcapillary reversed phase LC was performed with a CapLC ${ }^{\mathrm{TM}}$ (Waters) capillary system. Reversed phase separation of tryptic digests was performed with an Atlantis, $\mathrm{C}_{18}, 3 \mu \mathrm{m}, 75 \mu \mathrm{m}$ x $10 \mathrm{~cm}$ Nano Ease $^{\mathrm{TM}}$ fused silica capillary column (Waters) equilibrated in 5\% acetonitrile, $0.2 \%$ formic acid. After injection of $6 \mu \mathrm{l}$ of sample, the column was washed for 5 min with the same buffer and the peptides were eluted using a linear gradient of 5-50\% acetonitrile in 45 min at a constant flow rate of $0.2 \mu \mathrm{l} / \mathrm{min}$. The column was coupled online to a Q-TOF Micro (Waters) using a PicoTip nanospray ionization source (Waters). The heated capillary temperature was $80^{\circ} \mathrm{C}$ and the spray voltage was $1.8-2.2 \mathrm{kV}$. MS/MS data were collected in an automated data-dependent mode. The three most intense ions in each survey scan were sequentially fragmented by collision-induced dissociation (CID) using an isolation width of 2.0 and a relative collision energy of $35 \mathrm{~V}$. Data processing was performed with MassLynx 4.1. Database searching was carried out with ProteinLynx Global Server 2.1 (Waters) and Phenyx 2.2 (GeneBio, Geneva, Switzerland) against Uniprot knowledgebase Release 12.3 consisting of UniprotKB/Swiss-Prot Release 54.3 and UniprotKB/TrEMBL Release 37.3 with 285.335 and 4.932.421 entries, respectively. The search was enzymatically constrained for trypsin and 
allowed for one missed cleavage site. Further search parameters were as follows: no restriction on molecular weight and isoelectric point; fixed modification, carbamidomethylation of cysteine; variable modification, oxidation of methionine. Data were then manually inspected and the results were only accepted when the $M r$ and $\mathrm{p} I$ of the identified protein were coincident with the electrophoretic mobility of the corresponding spot on 2D.

RNA Isolation and quantitative RT-PCR

RNA was purified using TriZol reagent (Invitrogen Life Technologies, Carlsbad, CA, USA) according to the manufacturer's instructions. RNA (5ng) was reverse transcribed and the cDNA products amplified by qPCR using the GeneAmp Fast PCR Master Mix (Applied Biosystems, Foster City, CA, USA). All reactions were carried out in triplicate. Quantitative real-time PCR was run in the 7900HT Fast Real-Time PCR System. Pre-developed Taqman primers specific for CD and 18S were purchased from Applied Biosystems. Results were normalized according to $18 \mathrm{~S}$ quantification in the same sample reaction. Gene expression values were achieved by employing the equation:

Relative amount $=2^{-\Delta \mathrm{Ct}}$

wherein $\Delta \mathrm{Ct}$ stands for the difference between $\mathrm{Ct}$ values from the gene of interest and 18S.

\section{Enzymatic assay of Cathepsin D}

Cathepsin D protease activity was measured in the samples using the CD assay kit from Sigma (St. Louis, MO, USA) based on the method of Yasuda et al. [26]. Briefly, $5 \mu \mathrm{l}$ of tissue homogenates (1mg protein $/ \mathrm{ml}$ ) from lactating rats and mice or human CD $(2.4 \mu \mathrm{g} / \mathrm{ml})$ (Sigma) were added to the assay buffer $\mathrm{pH} 3.5$, followed by the addition of the quenched fluorometric substrate 7 -methoxycoumarin-4-acetic acid at a final concentration of $20 \mu \mathrm{M}$. The fluorescence released by the action of the enzyme was measured at $37^{\circ} \mathrm{C}$ in a fluorometric plate reader during 60 minutes incubation. To prove that substrate was hydrolyzed by CD only, the specific inhibitor pepstatin A (Psp. A) from Sigma, was added to parallel samples at a final concentration of $0.2 \mathrm{mg} / \mathrm{ml}$ to inhibit the CD activity (data not shown). Samples were assayed at least three times in triplicate. Data are given as the mean value \pm SEM.

\section{In vitro protein nitration}

Peroxynitrite was purchased from Calbiochem, suspended in $1,2 \mathrm{~N} \mathrm{NaOH}$ and stored in an oxygen-free atmosphere at $-80^{\circ} \mathrm{C}$ until use. Prior to experimentation, the concentration of ONOO $^{-}$was measured by the increase in absorbance at $302 \mathrm{~nm}\left(\varepsilon_{302 \mathrm{~nm}}=1,670 \mathrm{M}^{-1} \cdot \mathrm{cm}^{-1}\right)$ in $1.2 \mathrm{~N} \mathrm{NaOH}$ [27]. $20 \mu \mathrm{g}$ of recombinant CD from human liver (Sigma) or $50 \mu \mathrm{g}$ of proteins from control lactating mammary gland homogenates were reacted with $0-500 \mu \mathrm{M} \mathrm{ONOO}^{-}$in assay buffer, pH 3.5 (from the CD assay kit) in the presence or absence of $30 \mu \mathrm{M}(-)$ epicatechin (Sigma) in a total volume of $50 \mu \mathrm{l}$. The reaction was performed by placing a small aliquot of $\mathrm{ONOO}^{-}$in a tube containing the sample, immediately followed by 20 min incubation. In control tubes, the samples were treated with equal volumes of $1.2 \mathrm{~N} \mathrm{NaOH}$ (vehicle). Aliquots were taken for Western blot analysis and determination of enzymatic activity.

\section{Statistics}

Data are reported as means \pm SEM. In figures $4 \mathrm{~A}$ and $5 \mathrm{~A}$, Student's t test with the Bonferroni correction was used for comparison between two groups. This analysis was also used in figures $3 \mathrm{~A}$ and $\mathrm{B}$ to compare WT and KO mice at the same points of weaning. A difference was considered to be statistically significant when $\mathrm{p}<0.05$. For the rest of the figures, statistical significance was evaluated using one-way ANOVA. The homogeneity of the variances was analyzed by the Levene test; in those cases in which the variances were unequal, the data were adequately transformed before ANOVA. The null hypothesis was accepted for 
all the values of these sets in which the $F$-value was non-significant at $\mathrm{p}>0.05$. The data for which the $F$-value was significant were examined by Tukey's test at $\mathrm{p}<0.05$.

\section{RESULTS AND DISCUSSION \\ Nitroproteomic analysis of lactating and weaned mammary gland from rats}

In our previous work, using chromatin immunoprecipitation assays, it was demonstrated NF- $\mathrm{KB}$ binding to the iNOS promoter at the early onset of events triggered during weaning, resulting in the current transcription of the gene. This induction resulted in overproduction of NO during weaning, which led to an increase in the protein nitration pattern; however, this post-translational modification was limited to a few specific proteins [6].

The question raised in this study was to elucidate the functional consequences of protein nitration in our physiological model. Previous reports indicate that the nitration of protein tyrosine residues can alter protein function, either decreasing $[12,13]$ or increasing [14, $15,16]$ the catalytic activity. To identify the nitrated proteins in the weaned mammary gland, proteomic studies were performed. Figure 1 shows representative silver stained gels (Panel A) and nitrated proteins (Panel B) of whole tissue extracts from lactating and $72 \mathrm{~h}$ weaned mammary glands. As seen in figure $1 \mathrm{~B}$, protein nitration is increased during weaning. Nitrated proteins were identified using a combination of procedures that included 2D-PAGE immunoblotting with specific antibodies against nitrotyrosine residues and mass spectrometry of proteins recovered from 2D gels. Twenty proteins in the molecular mass range of 15 to 75 $\mathrm{kDa}$ and with an isoelectric point between 5 and 8 were identified by 2D IEF and MALDITOFMS. Since milk stasis plays an important role in the process of involution of the mammary gland after weaning, we were interested in the complete protein profile after weaning and therefore we did not use milk-depleted mammary tissue for our proteomic analysis. In consequence, we were unable to detect low abundant proteins, and therefore we cannot rule out the possibility that more proteins could be nitrated after weaning. The most general conclusion from the analysis of the protein map shown is a relative abundance of albumin, immunoglobulin chains, and casein fragments (data not shown), which is not surprising, due to milk stasis in the weaned mammary gland. Nevertheless, it is possible that these fragments of nitrated-albumin could play a more important role than one might think at first. Indeed, it has been described that the injection of small peptides derived from milk into the mammary gland accelerates the process of involution [28]. However, a $48 \mathrm{KDa}$ nitrated protein was identified, with coverage of $2.5 \%$, as cathepsin $\mathrm{D}$ in mammary gland $72 \mathrm{~h}$ after weaning.

An immunoprecipitation with CD antibody, followed by immunoblotting against nitrotyrosine residues, further confirmed the nitration of this enzyme after $72 \mathrm{~h}$ weaning. Two different forms of CD immunoprecipitated from the lactating mammary gland homogenates were nitrated. One is the mature single chain (msc) CD above the $43 \mathrm{KDa}$ molecular weight markers. The other corresponds to the heavy chain (34 KDa) from the mature double chain (mdc) form (Fig 1C left panel). Since it has been described that the msc accumulates in endosomes whilst the mdc is mainly found in lysosomes [21], the results presented here suggest that nitration takes place along the endosomal-lysosomal compartment. In the right panel, equal loading of both samples was assessed by loading on the gel $1 \%$ of control or weaned mammary gland homogenate (Input). Besides, to corroborate that CD was immunoprecipited, a western blot against CD was performed in the immunoprecipitate from $72 \mathrm{~h}$ weaned mammary gland (Fig. 1C right panel).

Since the relevance of cathepsin D nitration was critical to our findings, we wanted to ensure that this post-translational modification took place in our experimental model. Thus, another approach to purify CD from our samples was used. Pepstatin A (Psp A) is an inhibitor of $\mathrm{CD}$ that fits into the active site of the enzyme; we used Pst A-coated agarose beads to efficiently precipitate CD from weaned mammary gland homogenates. Those beads were 
incubated with $72 \mathrm{~h}$ weaned mammary gland homogenates, extensively washed and the bound fractions were analysed by western blotting, as described in the Experimental section. The detection of $\mathrm{CD}$ is shown in figure $1 \mathrm{D}$ and, the same membrane was reprobed with antinitrotyrosine antibody, which also immunoreacted with the same bands. This fact further demonstrated that CD becomes nitrated during weaning.

\section{Effect of weaning on the expression and activity of cathepsin $D$ in rat lactating mammary gland}

Since CD proteolytic activity has been generally involved in the apoptotic process, and forced weaning is known to induce apoptosis in lactating mammary tissue [2], CD mRNA and protein levels were studied at different times of weaning. Western blot analysis of lactating and weaned mammary gland lysates revealed two major CD-related bands that correspond to the enzymatically inactive precursor of $\sim 52 \mathrm{KDa}$ and the mature single chain form of $\sim 48 \mathrm{KDa}$. Figure 2A shows that the amount of the latter (msc) is increased after $8 \mathrm{~h}$ of pup removal and remains elevated 3 days later, being barely detectable thereafter. This increase in protein levels correlates with the accumulation of CD mRNA, measured by real time RT-PCR, which is maximal at 8 and $24 \mathrm{~h}$ after weaning (Fig 2B).

An enhancement of enzyme activity was expected due to the fact that the amount of msc CD increased with weaning (Fig 2A). However, when measuring CD proteolytic activity, it is noteworthy that it was not increased until $48 \mathrm{~h}$ after pup removal (Fig 2C). Although previous authors have reported a slight decrease in the proteolytic activity of this enzyme in rats weaned for $24 \mathrm{~h}$ [29], this was followed by an additional increase with maximal activity 4 days later [30]. This delay in the activation of the enzyme when compared to its protein levels suggests that a post-translational modification of $C D$ might be regulating its activity in our experimental model. In fact, we have described the physiological nitration of this proteinase during weaning (Fig 1C), and we hypothesize that this nitration could be involved in the modulation of CD activity.

\section{Evaluation of expression and activity of cathepsin D in iNOS -/- and WT mice}

In order to study the possible role of nitric oxide in the regulation of CD activity, studies were performed using knock-out mice for the iNOS gene. Those mice have an apparently normal lactation cycle and no clear differences were seen between iNOS -/- and wild type mice with respect to milk production and histological structures of the mammary gland (data not shown). As seen in Fig 3A, the activity of CD in weaned-glands of WT and KO mice was increased after 2 and 3 days post-weaning. Interestingly, when measuring CD activity, we found that mice deficient for iNOS showed decreased protease activity throughout involution compared to wild type animals (Fig 3A).

Since nitric oxide (NO) could be involved in the regulation of CD expression, we analyzed gene expression levels of this enzyme by real time PCR. However, when analyzing CD mRNA expression, no statistical differences were found between WT and iNOS -/- mice at each experimental point studied (Fig 3B). Furthermore, the increased pattern of expression seen in rats (Fig 2B) was similar to that observed in both types of mice, in which CD expression was increased at 1, 2 and 3 days post-weaning (Fig 3B).

On the other hand, NO could also be involved in protein stability or translational regulation, therefore CD protein levels were studied in WT and iNOS -/- mice. Western blot analysis demonstrated that there was no change in the protein levels of CD in KO versus WT mice at the same experimental time points. In both types of mice, the protein levels increased during weaning in a time-dependent manner. This increase was maximum for the pro-CD $(\sim$ $52 \mathrm{kDa}$ ) 2 days after weaning. The mature single chain (CD msc) was cleaved yielding the mature double chain form of CD (heavy and light chains were detected by the antibody giving 
immunoreactive bands of 30 and $14 \mathrm{kDa}$, respectively). In conclusion, the results obtained with iNOS -/- mice emphasize the importance of NO in CD activity regulation.

\section{Effect of in vitro peroxynitrite-induced nitration on cathepsin $D$ activity: Studies in rat mammary gland homogenates and in human recombinant cathepsin $D$.}

Mammary gland homogenates from control lactating rats were incubated with 0 to 500 $\mu \mathrm{M}$ peroxynitrite (ONOO$\left.{ }^{-}\right)$. CD activity was $50 \%$ higher at $20 \mu \mathrm{M}$ ONOO, compared to the control, but this increase was abolished in the presence of (-) epicatechin (Fig 4A). The flavonoid epicatechin has been shown to interfere with protein tyrosine nitration by intercepting the tyrosil radical [31]. However, at concentrations higher than $50 \mu \mathrm{M}^{\mathrm{ONOO}^{-}}$ there was a linear decrease in activity (data not shown). This observation can be attributed to the simultaneous oxidative effects of $\mathrm{ONOO}^{-}$on a variety of amino acid residues in addition to nitration of aromatic amino acids [32]. Since we wanted to study nitration within a physiological range, further characterization of the effects of high concentrations of $\mathrm{ONOO}^{-}$ was not pursued.

Western blot with 3-nitrotyrosine antibodies showed that protein nitration was enhanced after the incubation with $20 \mu \mathrm{M} \mathrm{ONOO}^{-}$and was undetectable either in control lactating rats treated with vehicle or with $\mathrm{ONOO}^{-}$and epicatechin, a nitration inhibitor (Fig $4 \mathrm{~B})$. In order to assess whether $\mathrm{CD}$ was nitrated after the incubation with $20 \mu \mathrm{M} \mathrm{ONOO}^{-}$, immunoprecipitation of control and nitrated samples with CD antibody was performed (Fig 4C). CD was immunoprecipitated from tissue lysates incubated with vehicle or $\mathrm{ONOO}^{-}$, and analyzed for tyrosine nitration by Western blotting. The results showed that nitrated CD was increased after peroxynitrite-induced nitration (Fig 4C right panel).

Although we have described for the first time CD nitration and this post-translational modification seems to correlate with increased catalytic activity, other proteins, also affected by NO, could be modulating CD activity indirectly. To gain a better understanding of the mechanisms by which protein nitration might affect CD activity, in vitro experiments with recombinant $C D$ from human liver were performed. As seen in figure $5 \mathrm{~A}$, the presence of peroxynitrite produced an increase in human $\mathrm{CD}$ activity. Epicatechin $(30 \mu \mathrm{M})$ completely abolished tyrosine nitration of recombinant human $\mathrm{CD}$ by $20 \mu \mathrm{M}$ peroxynitrite (Fig 5B). Moreover, epicatechin completely prevented the induction of CD activity by peroxynitrite (Fig. $5 \mathrm{~A}$ ), corroborating that this enzymatic activity is specifically modulated by tyrosine nitration.

The next question raised by this study is how nitration of this amino acid can affect CD activity. As already mentioned, immature CD can be partially autoactivated leading to the mature form of the enzyme, therefore a specific nitration could be somehow accelerating or interfering with the autoprocessing of the immature form of CD. However, our experiments with wild type and knock-out animals show the same pattern of proteolytic CD cleavage (Fig 4C). Moreover, it has been shown that pro-CD requires lysosomal cysteine proteinases for the final processing of its propart and we have shown that recombinant human CD undergoes in vitro nitration and activation in a cysteine protease-free buffer. Therefore, we can exclude the autoprocessing as the mechanism for the observed nitration-induced activity of CD.

These data suggest a conserved nitration domain among species since both rat and human CD can be nitrated in vitro by peroxynitrite (Fig 4C and 5B). Moreover, the fact that this nitration induced an increase in enzyme activity versus non-nitrated CD suggests that nitric oxide can modulate CD activity in a direct manner (Fig 5A). One could argue that the protein context surrounding $\mathrm{CD}$ or the conformation of $\mathrm{CD}$ in vivo could be other than that favoring the nitration. Nevertheless, we have shown that CD from extracts of control lactating mammary gland can also be nitrated in vitro (Fig 4), as demonstrated for the recombinant protein, and that this nitration induces an increase in the enzymatic activity (Fig 4A). On the whole, our experiments show that a low degree of nitration increases CD catalytic activity, not 
only in recombinant human $\mathrm{CD}$, but also in tissue homogenates, suggesting that direct nitration of this enzyme is responsible for the enhanced activity observed.

\section{Identification of the nitration site}

It has been shown that tyrosine nitration can dramatically induce profound changes in protein structure and function due to a shift in the pKa of the tyrosine hydroxyl group [33]. In order to identify the Tyr residue targeted by peroxynitrite, tryptic digests of nitrated and nonnitrated human recombinant CD were characterized by mass spectrometry. The doubly charged ion with $\mathrm{m} / \mathrm{z} 823.92$ was assigned as the nitrated form of peptide (159)LVDQNIFSFYLSR(171). All y ions from y4 showed the extra 45 Da suggesting the nitration of $\mathrm{Tyr}^{168}$. In contrast, no nitrations were detected when tryptic digests from control CD were analyzed. In particular, a doubly charged ion with $\mathrm{m} / \mathrm{z} 801.42$ was assigned as the non-nitrated (159)LVDQNIFSFYLSR(171) peptide (Fig 6).

Nevertheless, although we could sequence most of the tyrosine residues present in the protein (13 Tyr residues out of 19), we were unable to sequence more than $40 \%$ of the human CD and therefore we cannot rule out the possibility that other tyrosines could also be nitrated. As shown in figure $7, \operatorname{Tyr}^{168}$ is found in the heavy chain of CD and is highly conserved among species and other proteases, such as human renin, porcine pepsin, and bovine chymosin. In fact, the detailed protein sequence analysis reveals a possible nitration domain with the sequence F S F/V Y X X R/S. Further studies would be needed in order to determine whether other proteinases with this conserved domain can also undertake an in vivo and in vitro nitration.

The important role played by $\mathrm{pH}$ in the modulation of CD activity has been extensively documented [22, 34, 35]. Indeed, while an acidic $\mathrm{pH}$ lead to a fully active enzyme, at pH 7.5 a molecular bond between specific tyrosines and the catalytic aspartates stabilizes the protein structure in an inactive conformation [36]. Although $\mathrm{Tyr}^{168}$ is $17.76 \AA$ away from the active site and such a distance is not compatible with a direct hydrogen bond with the catalytic residues, it would be conceivable that the nitration of $\mathrm{Tyr}^{168}$ could favor an irreversible active conformation of the enzyme by blocking a molecular bond crucial for CD folding. Moreover, an inhibitory domain has been localized at the N-terminus of CD [36]; at pH 7.5 the mature Nt is repositioned into the active site cleft, interacting with the catalytic residues. Since we cannot exclude the possibility of nitration in other non-identified tyrosine residues, the in vivo nitration of a specific Tyr at this site could block the binding of the inhibitory propeptide and allow the free access of the substrate.

\section{Physiological and medical implications}

All in all, in the future it would be very interesting to further investigate the mechanisms of modulation of CD activity induced by both nitration and nitrosylation, as well as the possibility of finding more tyrosine and/ or cysteine residues modified by nitric oxide. The relevance of these findings is granted by the fact that CD is known to be involved in pathological processes, such as inflammation, tumor progression, and metastasis. Indeed, CD is an independent marker of poor prognosis in human breast cancer [37, 38]. Recently published studies have demonstrated a direct relationship between thrombin and CD up-regulation which would enhance angiogenesis, tumor growth and metastasis [39]. Regarding to CD activity, is 8 to 16 times higher in the cytosol of mammary cancer cells than in normal cells [40]. A direct relationship between CD activity and the metastatic potential of tumors has been demonstrated [41] although a mutated CD devoid of its catalytic activity also stimulates the growth of cancer cells, suggesting a novel mechanism by which CD could act as a mitogen in tumor progression [42]. Nevertheless, little is known about the molecular mechanisms involved in the modulation of CD activity in all these processes, or how tyrosine-nitration could affect protein function. 
In summary, mammary gland involution is physiologic, orderly, and developmentally programmed. Thus, the involuting mammary gland is an ideal physiological model to search for genes involved in growth arrest, differentiation, and apoptosis. These processes are known to play an important role in cancer and other pathologies, therefore those genes relevant to involution in the normal mammary gland may be highly relevant in breast cancer. A pilot study using cDNA microarrays has demonstrated that through the analysis of differentially expressed genes during early mammary gland involution it may be possible to identify "novel" genes relevant to human breast cancer [43]. This can also be applied to CD; the activation of this protein plays a key role in mammary gland involution, but more importantly, the involuting mammary gland offers an excellent experimental model for studying the mechanisms of CD activation that could also apply for breast cancer development.

\section{ACKNOWLEDGEMENTS AND FUNDINGS}

We thank Mrs. Marilyn R. Noyes for kindly revising the manuscript.

This work was supported in part by grants from Ministerio de Educación y Ciencia [BFU200762036 to J.R.V.; CIT-010000-2007-51 to L.T. and J.R.V. and Programa Ramón y Cajal to E.R.G-T]; Ministerio de Sanidad [FIS PI05/1332 to E.R.G-T] and Consellería de Sanidad [AP061/08 to R.Z.]. R.Z is a fellow from Ministerio de Educación y Ciencia (Programa Juan de la Cierva).

\section{REFERENCES}

1 Vorbach, C., Capecci, M.R. and Penninger, J.M. (2006) Evolution of the mammary gland from the innate immune system? Bioessays 28, 606-616

2 Green, K.A. and Streuli, C.H. (2004) Apoptosis regulation in the mammary gland. Cell. Mol. Life Sci. 61, 1867-1883

3 Baxter, F.O., Neoh, K. and Tevendale, M.C. (2007) The beginning of the end: death signaling in early involution. J. Mammary Glan Biol. Neoplasia 12, 3-13

4 Clarkson, R.W.E., Wayland, M.T., Lee, J., Freeman, T., and Watson, C.J. (2004) Gene expression profiling of mammary gland development reveals putative roles for death receptors and immune mediators in post-lactational regression. Breast Cancer Res. 6, R92-R109

5 Stein, T., Morris, J.S., Davies, C.R., Weber-Hall, S.J., Duffy, M-A., Heath, V.J., Bell, A.K., Ferrier, R.K., Sandilands, G.P., and Gusterson, B.A. (2004) Involution of the mouse mammary gland is associated with an immune cascade and an acute-phase response, involving LBP, CD14 and STAT3. Breast Cancer Res. 6, R75-R91

6 Zaragozá, R., Miralles, V.J., Rus, A.D., García, C., Carmena, R., García-Trevijano, E.R., Barber, T., Pallardó, F.V., Torres, L., \& Viña, J.R. (2005) Weaning induces NOS-2 expression through NF-kappa modulation in the lactating mammary gland: importance of GSH. Biochem. J. 391, 581-588

7 Chapman, R.S., Lourenco, P.C., Tonner, E., Flint, D.J., Selbert, S., Takeda, K., Akira, S., Clarke, A.R. and Watson, C.J. (1999) Supression of epithelial apoptosis and delayed mammary gland involution in mice with a conditional knockout of Stat3. Genes Dev. 13, 2604-2616

8 Baxter, F.O., Came, P.J., Abell, K., Kedjouar, B., Huth, M., Rajewsky, K., Pasparakis, M. and Watson, C.J. (2006) IKK $\beta / 2$ induces TWEAK and apoptosis in mammary epithelium. Development 133, 3485-3494

9 Dietze, E.C., Caldwell, L.E., Marcom, K., Collins, S.J., Yee, L., Swisshelm, K., Hobbs, K.B., Bean, G.R. \& Seewaldt, V.L. (2002) Retinoids and retinoic acid receptors regulate growth arrest and apoptosis in human mammary epithelial cells and modulate expression of CBP/p300. Microsc. Res. Tech. 59, 23-40 
10 Zaragozá R., Miralles V.J., García-Trevijano E.R., Carmena R., García C., Mata M., Puertes I.R., Torres L., Viña J.R. \& Gimeno A. (2007) Retinoids induce MMP-9 expression through RAR $\alpha$ during mammary gland remodelling. Am. J. Physiol. (Endocrinol Metab.) 292, E1140E1148

11 Clarkson, R.W.E., Heeley, J.L., Chapman, R., Aillet, F., Hay, R.T., Wyllie, A., and Watson, C.J. (2000) NF-кB inhibits apoptosis in murine mammary epithelia. J. Biol. Chem. 275, 1273712742

12 MacMillan-Crow, L.A., Crow, J.P. and Thompson, J.A. (1998) Peroxynitrite-mediated inactivation of manganese superoxide dismutase involves nitration and oxidation of critical tyrosine residues. Biochemistry 37, 1613-1622

13 Görg, B., Qvartskhava, N., Voss, P., Grune, T., Häussinger, D. and Schliess, F. (2007) Reversible inhibition of mammalian glutamine synthetase by tyrosine nitration. FEBS letters 581, 84-90

$14 \mathrm{Ji}, \mathrm{Y}$. and Bennett, B.M. (2003) Activation of microsomal glutathione S-transferase by peroxynitrite. Mol. Pharmacol. 63, 136-146

$15 \mathrm{Ji}$, Y., Neverova, I., Van Eyk, J.E. and Bennett, B.M. (2006) Nitration of tyrosine 92 mediates the activation of rat microsomal glutathione S- transferase by peroxynitrite. J. Biol. Chem. 281, 1986-1991

16 Rebrin, I., Brégère, C., Kamzalov, S., Gallaher, T.K. and Sohal, R.S. (2007) Nitration of tryptophan 372 in succinyl-CoA:3-ketoacid CoA transferase during aging in rat heart mitochondria. Biochemistry 46: 10130-10144

17 Tang, J. and Wong, R.N. (1987) Evolution in the structure and function of aspartic proteases. J. Cell Biochem. 33, 53-63

18 Saftig, P. Hetman, M., Schmahl, W., Weber, K., Heine, L., Mossmann, H., Köster, A., Hess, B., Evers, M., von Figura, K., et al (1995) Mice deficient for the lysosomal proteinase cathepsin D exhibit progressive atrophy of the intestinal mucosa and profound destruction of lymphoid cells. EMBO J. 14, 3599-3608

19 Rochefort, H. and Liaudet-Coopman, E. (1999) Cathepsin D in cancer metastasis: a protease and a ligand. APMIS 107, 86-95

20 Castino, R., Bellio, N., Nicotra, G., Follo, C., Trinchera, N.F. and Isidoro, C. (2007) Cathepsin D-Bax death pathway in oxidative stressed neuroblastoma cells. Free Rad. Biol. Med. 42, 1305-1316

21 Castino, R., Delpal, S., Bouguyon, E., Demoz, M., Isidoro, C. and Ollivier-Bousquet, M. (2008) Prolactin promotes the secretion of active cathepsin D at the basal side of rat mammary acini. Endocrinol. 149: 4095-4105

22 Khalkhali-Ellis, Z., Abbott, D.E., Bailey, C.M., Goossens, W., Margaryan, N.V., Gluck, S.L., Reuveni, M. and Hendrix, M.J.C. (2008) IFN- $\gamma$ regulation of vacuolar $\mathrm{pH}$, cathepsin D processing and autophagy in mammary epithelial cells. J. Cell Biochem. 105: 208-218

23 Zaragozá, R., García, C., Rus, A.D., Pallardó, F.V., Barber, T., Torres, L., Miralles, V.J. and Viña, J.R. (2003) Inhibition of liver trans-sulphuration pathway by propargylglycine mimics gene expression changes found in the mammary gland of weaned lactating rats: role of glutathione. Biochem. J. 373, 825-834

24 Follo, C., Castino, R., Nicotra, G., Trincheri, N.F. and Isidoro, C. (2007) Folding, activity and targeting of mutated human cathepsin $\mathrm{D}$ that cannot be processed into the double-chain form. Int. J. Biochem. Cell Biol. 39, 638-649

25 Muñoz, J., Fernández-Irigoyen, J., Santamaría, E., Parbel, A., Obeso, J. and Corrales, F.J. (2008). Mass spectrometric characterization of mitochondrial complex I NDUFA10 variants. Proteomics. 8,1898-1908 
26 Yasuda, Y., Kageyama, T, Akamine, A. et al (1999) Characterization of new fluorogenic substrates for the rapid and sensitive assay of cathepsin E and cathepsin D. J. Biochem. 125, 1137-1143

27 Radi, R., Beckman, J.S., Bush, K.M. and Freeman, B.A. (1991) Peroxynitrite oxidation of sulfhydryls. The cytotoxic potential of superoxide and nitric oxide. J. Biol. Chem. 266, 42444250

28 Shamay, A., Shapiro, F., Mabjeesh, S.J. and Silanikove, N. (2002) Casein-derived phosphopeptides disrupt tight junction integrity, and precipitously dry up milk secretion in goats. Life Sci. 70, 2707-2719

29 Hernández-Montes, H., Escudero, I. and Villalpando, S. (1999) Changes in cathepsin D activity of maternal tissues during lactation and weaning in rats. Arch. Med. Res. 30, 10-13

30 Helminen, H.J., Ericsson, J.L.E. and Orrenius, S. (1968) Studies on mammary gland involution. IV. Histochemical and biochemical observations on alterations in lysosomes and lysosomal enzymes. J. Ultrastruct. Res. 25, 240-252

31 Schroeder, P., Klotz, L.O., Buchczyk, D.P., sadik, C.D., Schewe, T. and Sies, H. (2001) Epicatechin prevents nitration but not oxidation reactions of peroxynitrite. Biochem. Biophys. Res. Commun. 285, 782-787

32 Alvarez, B. and Radi, R. (2003) Peroxynitrite reactivity with amino acids and proteins. Amino Acids 25, 295-311

33 Sokolovsky, M., Riordan, J.F. and Vallee, B.L. (1967) Conversion of 3-nitrotyrosine to 3aminotyrosine in peptides and proteins.Biochem. Biophys. Res. Commun. 27, 20-25

34 Matsuyama, S., Llopis, J, Deveraux, Q.L., Tsien, R.Y. and Reed, J.C. (2000) Changes in intramitochondrial and cytosolic $\mathrm{pH}$ : early events that modulate caspase activation during apoptosis. Nat. Cell Biol. 2, 318-325

35 Beaujouin, M. and Liaudet-Coopman, E. (2008) Cathepsin D overexpressed by cancer cells can enhance apoptosis-dependent chemo-sensitivity independently of its catalytic activity. Adv. Exp. Med. Biol. 617, 453-461

36 Mása, M., Maresová, L., Vondrásek, J., Horn, M., Jezek, J. and Mares, M. (2006) Cathepsin D propeptide: Mechanism and regulation of its interaction with the catalytic core. Biochemistry 45, 15474-15482

37 Bossard, N., Descotes, F., Bremond, A.G., Bobin, Y., De Saint Hilaire, P., Golfier, F., Awada, A., Mathevet, P.M., Berrerd, L., Barbier, Y. and Estève J. (2003) Breast Cancer Res. Treat. 82, 47-59

38 Benes, P., Vetvicka, V. and Fusek, M. (2008) Cathepsin D- Many functions of one aspartic protease. Crit. Rev. Oncol. Hematol. 68, 12-28

39 Hu, L., Roth, J.M., Brooks, P., Luty, J. and Karpatkin, S. (2008) Thrombin up-regulates cathepsin D which enhances angiogenesis, growth and metastasis. Cancer Res. 68, 4666-4673 40 Capony, F., Rougeot, C.I., Montcourrier, P., Cavailles, V., Salazar, G. and Rochefort, H. (1989) Increased secretion, altered processing and glycosylation of pro-cathepsin D in human mammary cancer cells. Cancer Res. 49, 3904-3909

41 Pujol, P., Maudelonde, T., Daures, J.P., Rouanet, P., Brouillet, J.P., Pujol, H. and Rochefort, H. (1993) A prospective study of the prognostic value of cathepsin D levels in breast cancer cytosol. Cancer 71, 2006-2012

42 Glondu, M., Coopman, P., Laurent-Matha, V., Garcia, M., Rochefort, H. and LiaudetCoopman, E. (2001) A mutated cathepsin-D devoid of its catalytic activity stimulates the growth of cancer cells. Oncogene 20, 6920-6929

43 Blanchard, A., Shiu, R., Booth, S., Sorensen, G., DeCorby, N., Nistor, A., Wong, P., Leygue, E. and Myal, Y. (2007) Gene expression profiling of early involuting mammary gland reveals novel genes potentially relevant to human breast cancer. Front Biosci. 12, 2221-2232 


\section{FIGURE LEGENDS}

FIGURE 1.Cathepsin D nitration in mammary glands from weaned rats. Protein expression profiles of control lactating and 72 hours weaned mammary glands separated by IEF 2D PAGE and silver stained (A) or staining of nitrated proteins by immunoblotting with anti-nitrotyrosine antibody (B). The $\mathrm{pH}$ increases from left to right on the abscissa and the molecular mass decreases from top to bottom on the ordinate. Molecular weight markers (kilodaltons) are on the left of the gel. (C) Tissue homogenates from control lactating or $72 \mathrm{~h}$ weaned $(72 \mathrm{~h} \mathrm{~W})$ mammary glands were immunoprecipitated (IP) by anti-cathepsin D antibody (Santa Cruz Biotech.), and the precipitates were then immunoblotted (IB) with antinitrotyrosine antibody (Upstate) or cathepsin D antibody (Calbiochem). Position of the molecular weight markers (kilodaltons) is on the left. (D) Mammary gland homogenates from $72 \mathrm{~h}$ weaned rats $(72 \mathrm{~h} \mathrm{~W})$ were incubated with pepstatin A-coated agarose beads. After elution, the bound fraction was analysed by western blotting, including an equal amount of starting homogenate (named INPUT). The membrane was immunoblotted (IB) with CD antibody (Calbiochem) and then stripped and re-probed with anti-NO tyrosine to verify protein nitration.

FIGURE 2.Characterization of mammary gland CD from control lactating and weaned rats. (A) Proteins from mammary gland homogenates were analyzed by SDS-PAGE and treated for immunoblotting as described in Materials and Methods. Two immunoreactive bands, corresponding to pro-cathepsin $\mathrm{D}$ (proCD) and mature single chain CD (CD msc) forms of $C D$ were visualized in control and weaned rats using the CD antibody from Santa Cruz biotech. Position of the molecular weight markers (kilodaltons) is on the right. (B) CD mRNA expression in rat mammary tissue at the peak of lactation (control) and at different times of weaning, measured by real time RT-PCR. 18S was used as internal control (see Experimental section). Results are mean \pm SEM for three independent experiments. (C) CD activity in mammary gland from control lactating and weaned rats by measurement of the hydrolysis of the fluorogenic substrate 7-methoxycoumarin-4-acetic acid as described in Materials and Methods ( $n=4$ per group). In (B) and (C), ANOVA was performed for the statistical analysis where different superscript letters indicate significant differences, $\mathrm{P}<0.05$; the letter "a" always represents the lowest value within the group.

FIGURE 3. Expression of CD and proteolytic activity in iNOS -/- mice. (A) Lactating and weaned mammary glands were collected from wild type (WT) and inducible NOS null mice (KO) and analyzed for CD activity ( $n=4$ per group). (B) Gene expression of CD from wild type and iNOS -/-mice during lactation and weaning ( $n=4$ per group). In (A) and (B), to compare between the different conditions in WT or KO mice, ANOVA was performed for the statistical analysis where different superscript letters indicate significant differences, $\mathrm{P}<0.05$; the letter "a" always represents the lowest value within the group. Student's $t$ test with the Bonferroni correction was used for comparison between WT and KO at each experimental time point, *, P<0.05. (C) Western blot analysis of CD at the peak of lactation (control) and during mammary gland involution (weaning) in wild type and iNOS -/- mice. The blot shows the presence of precursor (pro-CD) and mature single chain (CD msc) forms of CD recognized with the CD antibody from Santa Cruz Biotech. Since this antibody doesn't immunoreact with the mature double chain, the two degradation products of $\sim 30 \mathrm{KDa}$ (CD heavy chain) and $\sim 14$ KDa (CD light shain) are recognized with the CD antibody from R\&D Systems. The blot shows a representative example from one individual mouse from each group. The molecular forms of CD are indicated on the left and the molecular weight markers (KDa) in the middle of both blots. 
FIGURE 4. In vitro nitration of lactating mammary gland homogenates. Lactating mammary gland lysates were incubated with 0 or $20 \mu \mathrm{M} \mathrm{ONOO}^{-}(\mathrm{PN})$ in the presence or absence of (-) epicatechin. (A) The graph shows the increase in CD activity in the nitrated sample $(20 \mu \mathrm{M} \mathrm{PN})$ when compared to control (treated with vehicle) or to lactating mammary gland homogenate treated simultaneously with PN and epicatechin (PN + Epic.). The increase in $\mathrm{CD}$ activity induced by $\mathrm{PN}$ was statistically significant. *, $\mathrm{P}<0.05$. (B) A representative Western blot against tyrosine-nitrated residues or CD (with the Santa Cruz antibody) in samples from mammary tissue after treatment with $\mathrm{ONOO}^{-}$is shown. (C) Tissue homogenates from control lactating mammary glands treated with vehicle (control) or with $\mathrm{ONOO}^{-}(20 \mu \mathrm{M}$ PN) were immunoprecipitated (IP) by anti-cathepsin D antibody (Santa Cruz Biotech.), and the precipitates were then immunoblotted (IB) with anti-nitrotyrosine antibody (Right panel) or cathepsin D antibody from Calbiochem (Left panel). Molecular weight markers (KDa) are indicated on each blot.

FIGURE 5. Peroxynitrite-induced activation of cathepsin D. Commercial human CD reacted with 0 or $20 \mu \mathrm{M} \mathrm{ONOO}^{-}(\mathrm{PN})$ in the presence or absence of (-) epicatechin. This recombinant $\mathrm{CD}$ from human liver corresponds mainly to the heavy chain of the mature $\mathrm{CD}$ form (34 KDa). Samples were analyzed for tyrosine nitration or CD activity. (A) Effect of $20 \mu \mathrm{M} \mathrm{ONOO}^{-}$on human CD activity. A significant increase $(*, \mathrm{P}<0.05)$ is observed after the addition of PN. (B) CD samples from human liver, treated with vehicle (control), $\mathrm{ONOO}^{-}$(PN) and $\mathrm{ONOO}^{-}$and epicatechin (PN + epic.), were analyzed for tyrosine-nitrated and overall CD (using the mouse monoclonal anti-human CD antibody from Calbiochem) by Western blot. Immunoblots are representative of three separate experiments and position of the molecular markers $(\mathrm{KDa})$ is on the right.

FIGURE 6. Identification of the modified amino acid by mass spectrometry. Representative MS/MS spectra of tryptic digests from human cathepsin D (A) vehicle or (B) $\mathrm{ONOO}^{-}$-treated are shown. The mass/charge value of 823.92 for the peptide (159)LVDQNIFSFYLSR(171) from CD treated with ONOO- contains a +45 Da adduct when compared to the vehicle-treated enzyme (m/z of 801.42), suggesting the nitration of $\mathrm{Tyr}^{168}$.

FIGURE 7. Sequence alignments for the mammalian aspartic proteases: cathepsin $\mathbf{D}$, cathepsin E, renin, pepsin, and chymosin. The possible nitration domain, which is highly conserved among different proteinases, is bolded in grey. Key: CD, cathepsin D; CE, cathepsin E; REN, renin; CHY, chymosin; PEP, pepsin. Sequence sources: Cathepsin D: Swissprot entries CATD_HUMAN, MOUSE and RAT. Cathepsin E: Swissprot entries CATE_HUMAN, MOUSE and RAT. Renin: Swissprot entries RENI_HUMAN. Chymosin: Swissprot entries CHYM_BOVIN. Pepsin: Swissprot entries PEPA_PIG. 


\section{Figure 1.}

A)

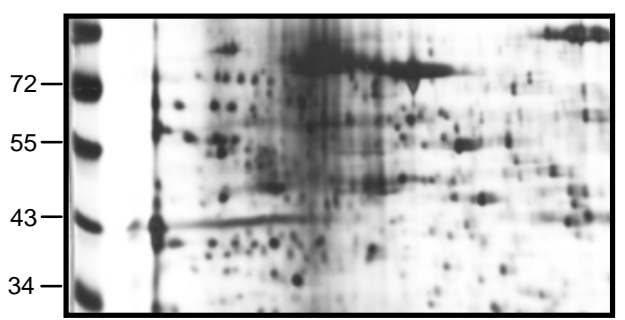

Control lactating

B)

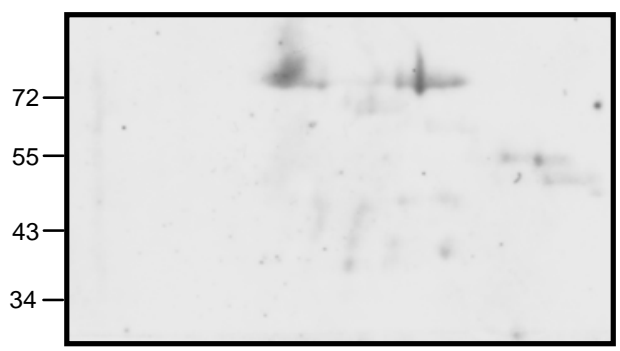

Control lactating
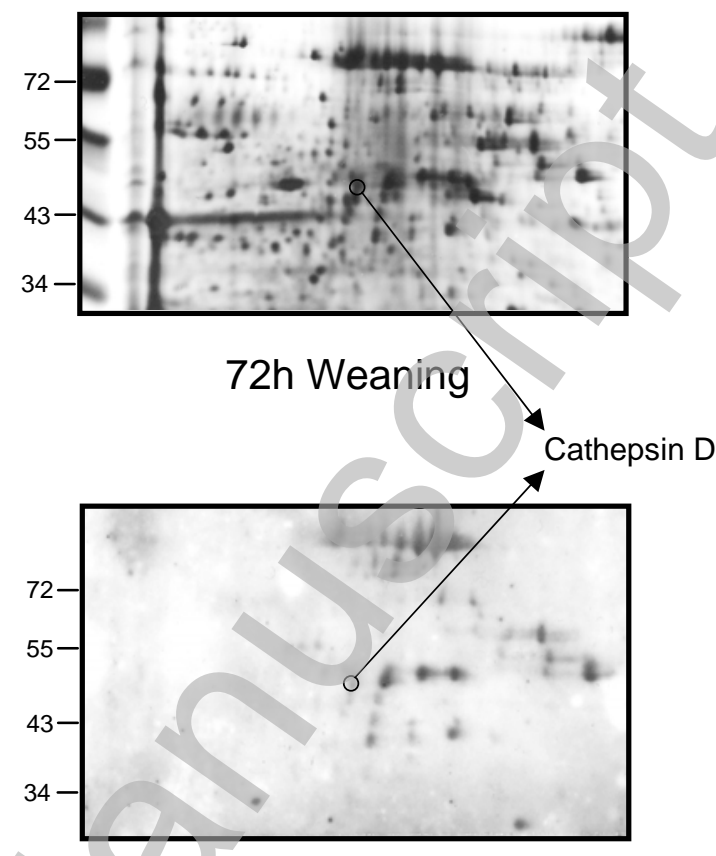

72h Weaning

C)

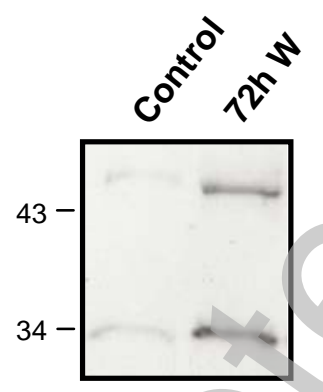

IP: $\alpha$-Cathepsin D

IB: $\alpha$-NO Tyr

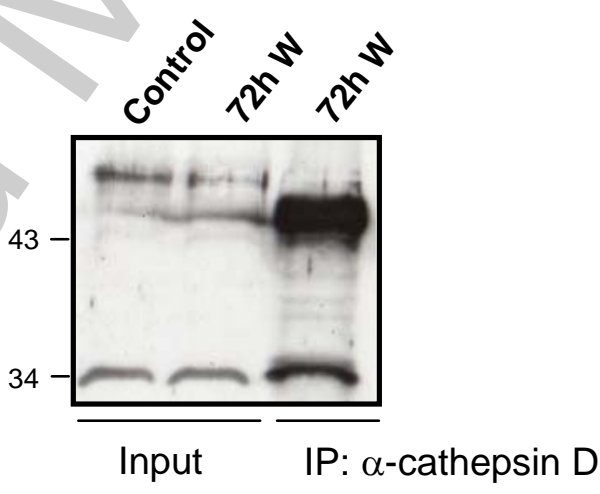

IB: $\alpha$-Cathepsin D

D)

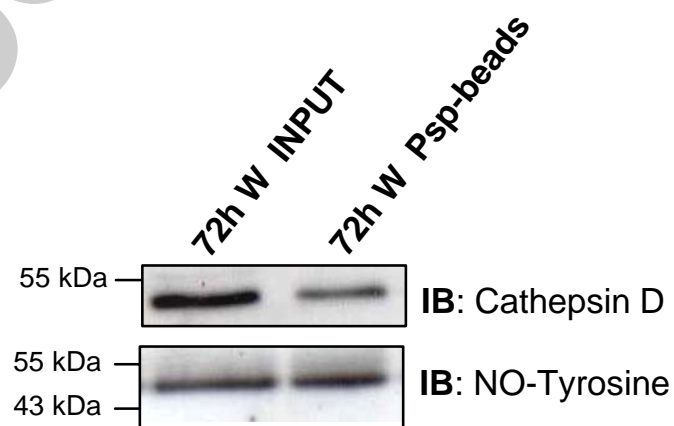




\section{Figure 2.}

A)

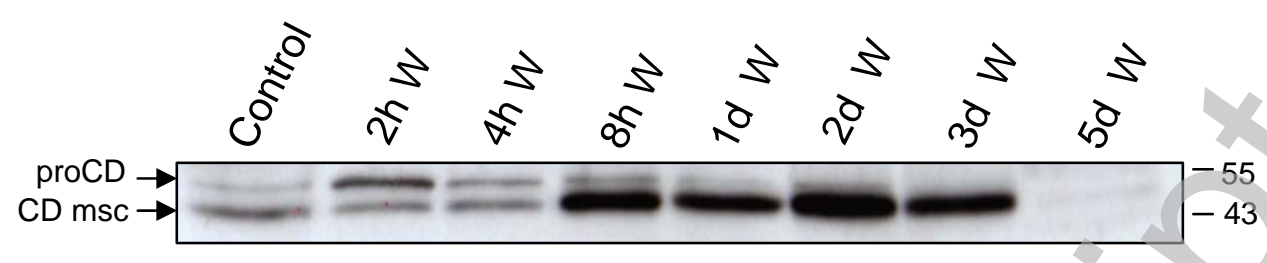

B)



C)

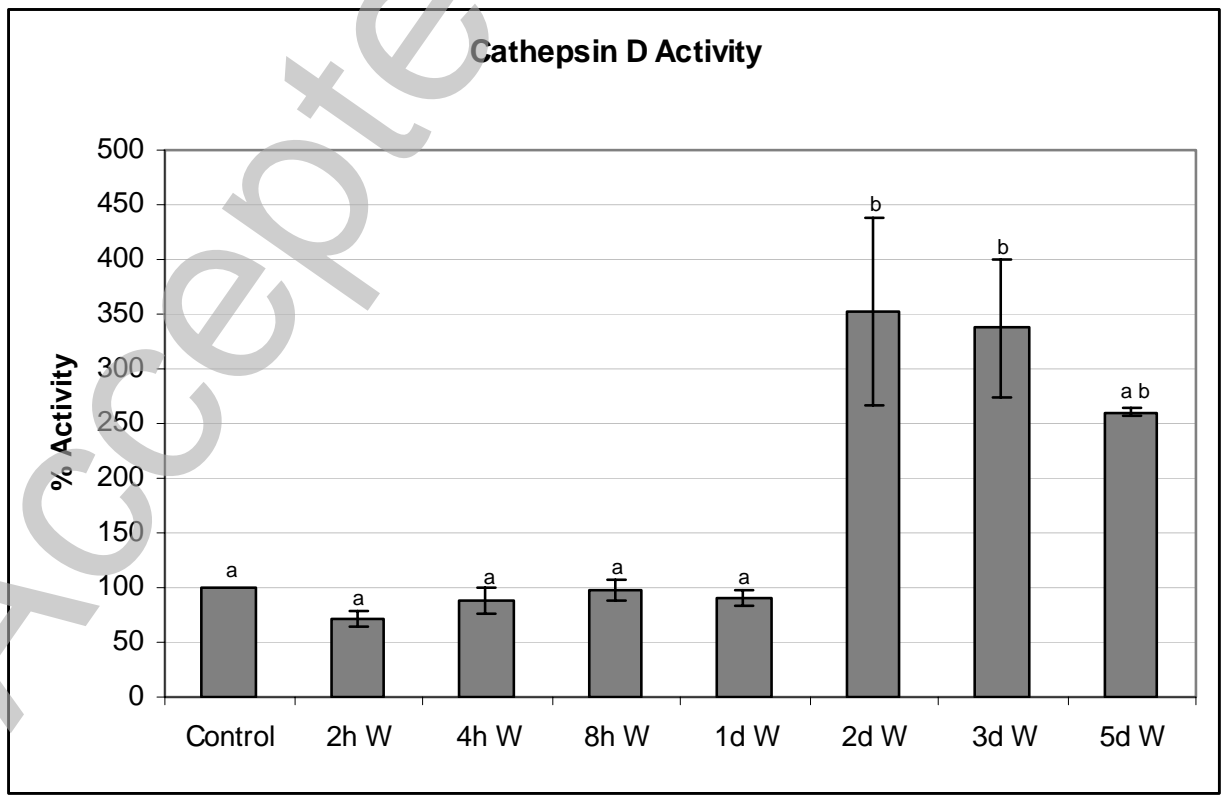

Licenced copy. Copying is not permitted, except with prior permission and as allowed by law. (C) 2009 The Authors Journal compilation (c) 2009 Portland Press Limited 
Figure 3.

A)

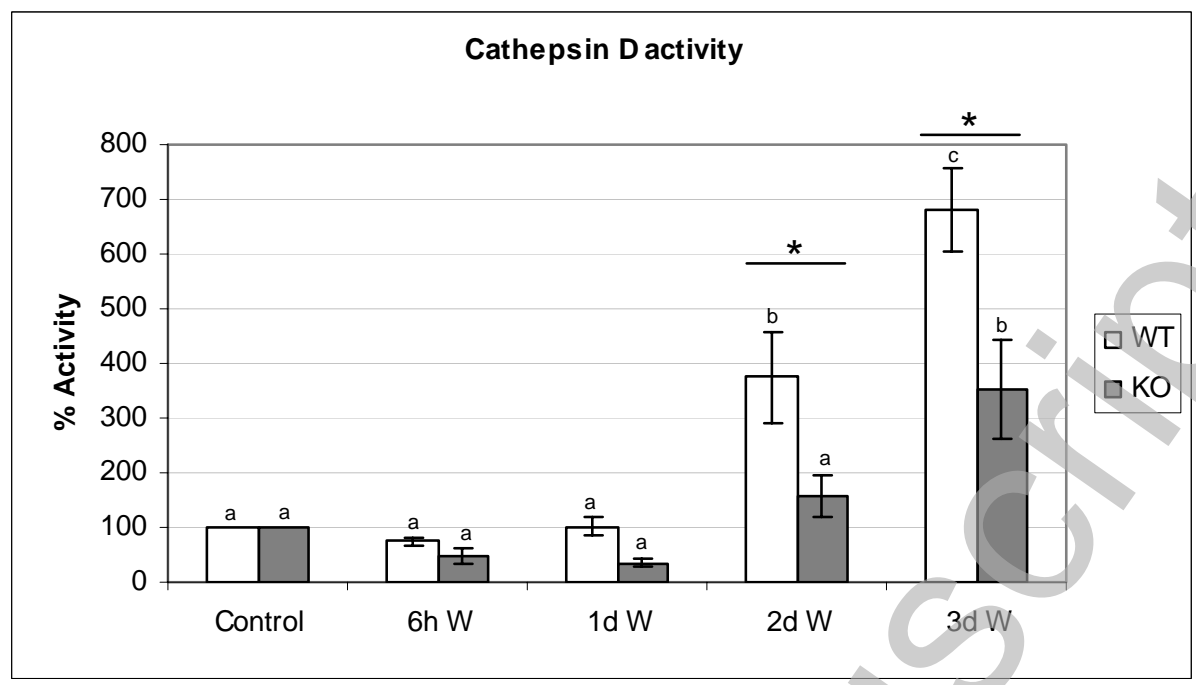

B)

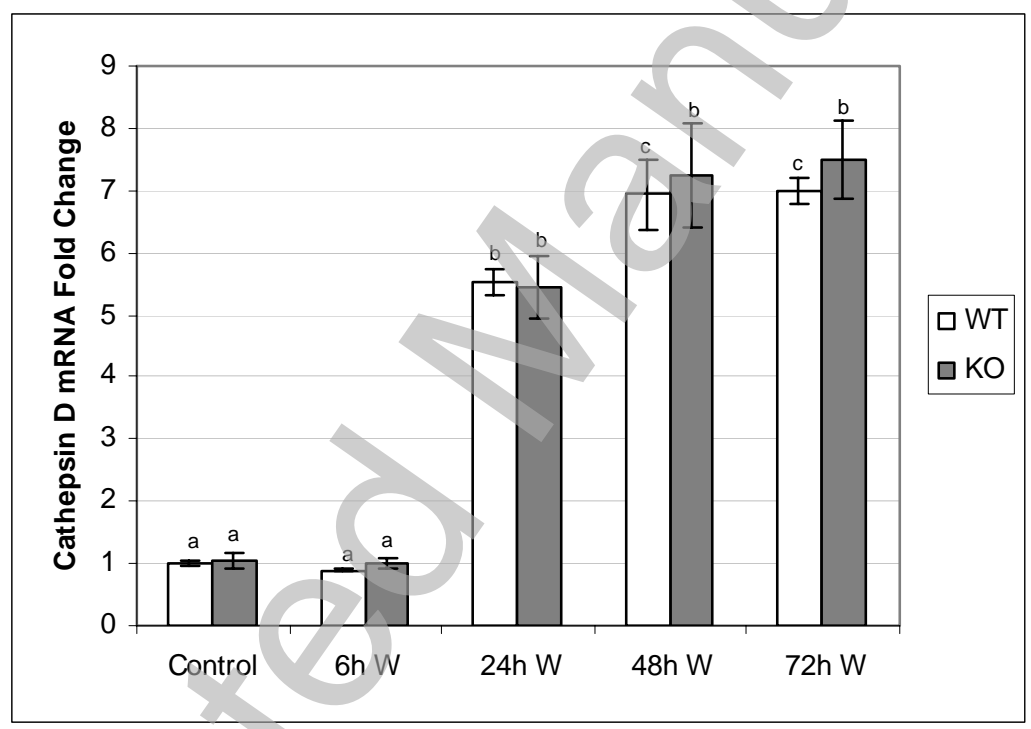

C)

Wild Type

Knock Out

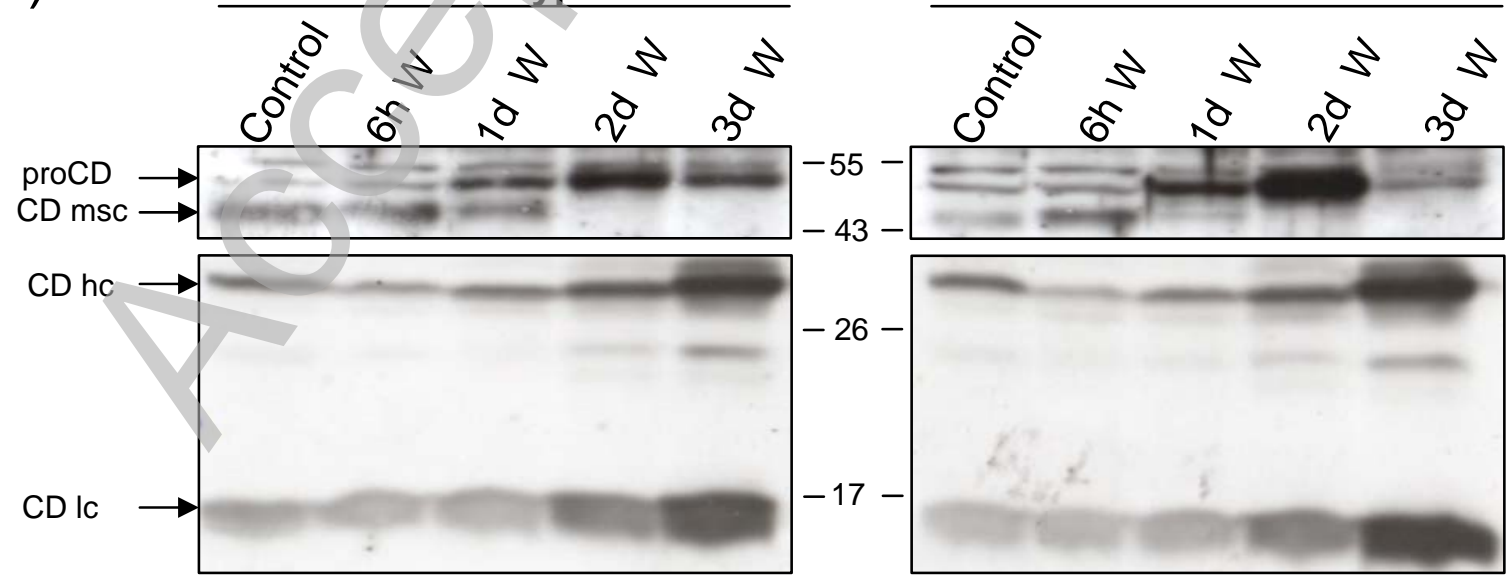

Licenced copy. Copying is not permitted, except with prior permission and as allowed by law. (C) 2009 The Authors Journal compilation (c) 2009 Portland Press Limited 
Figure 4.

A)

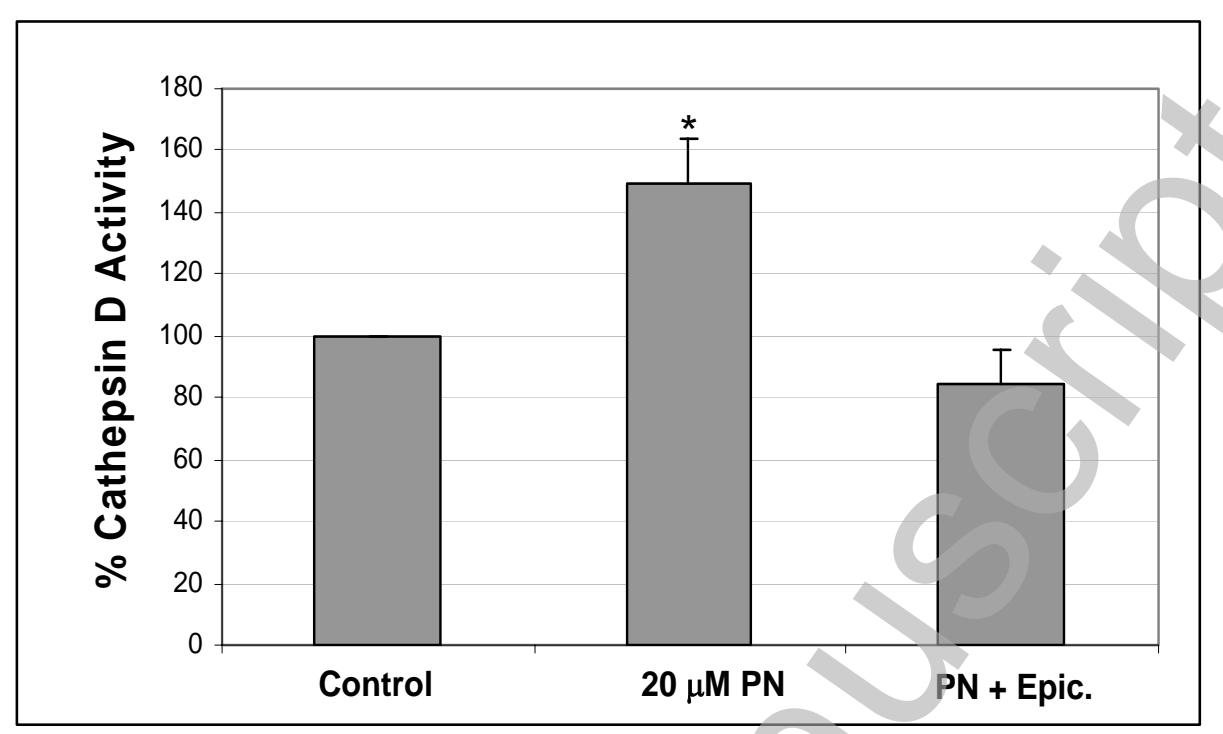

B)

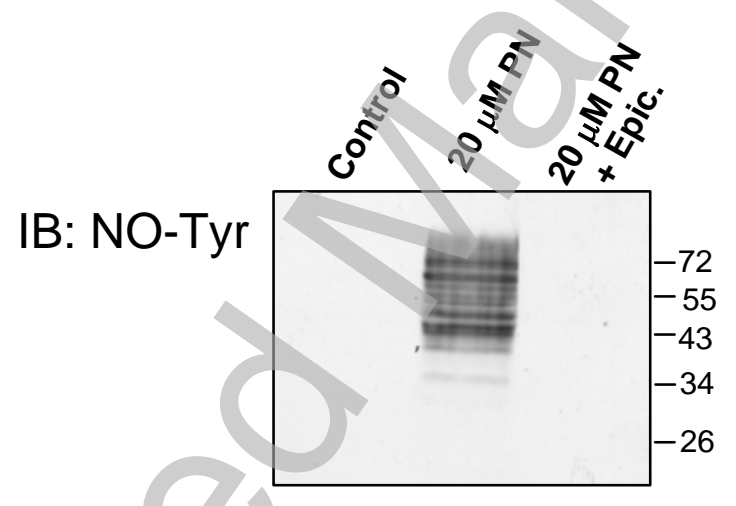

IB: CD

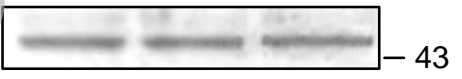

C)

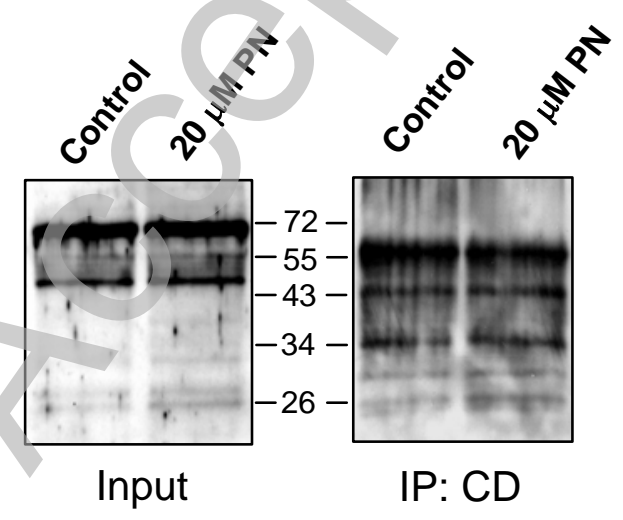

IB: CD

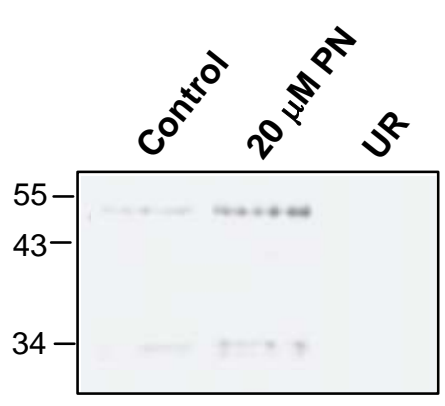

IP: CD

IB: NO Tyr 


\section{Figure 5.}

A)

B)
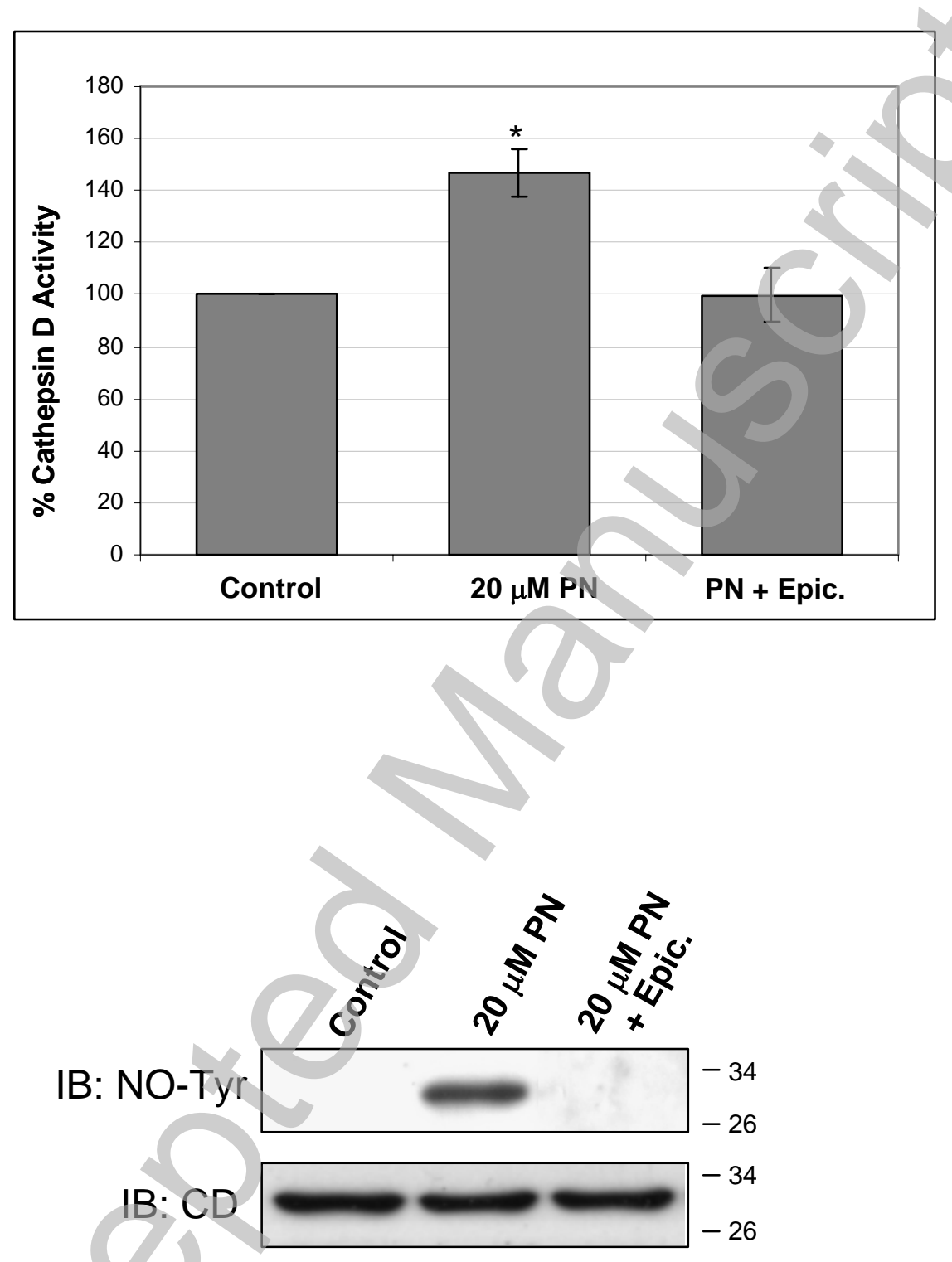


\section{Figure 6.}

A)

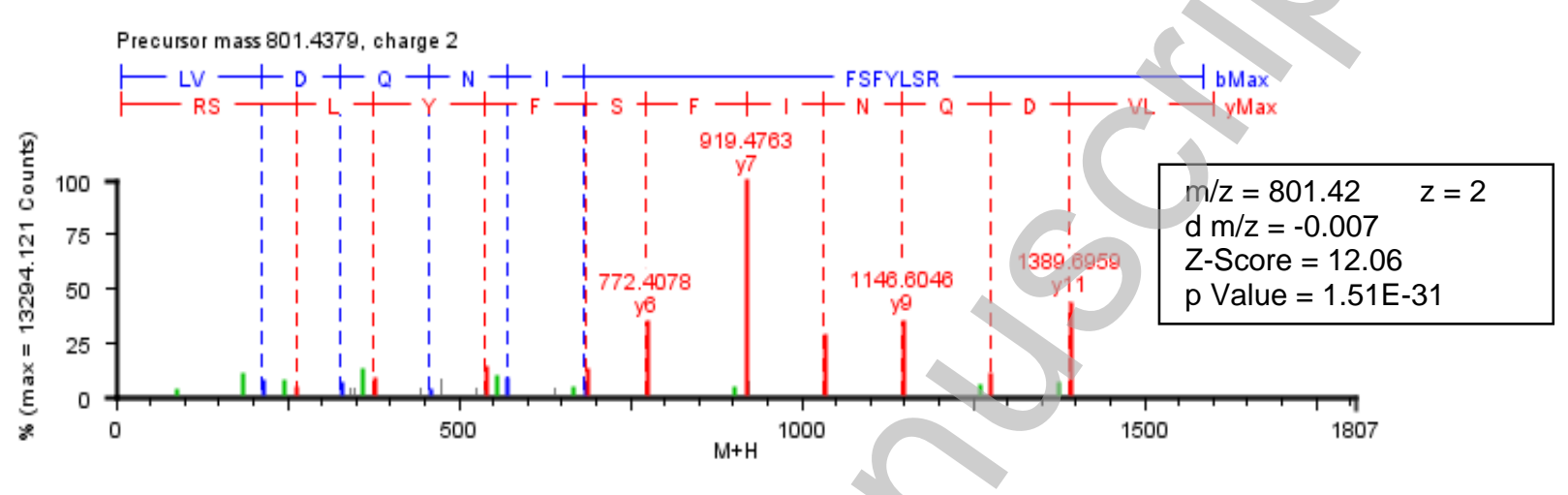

B)

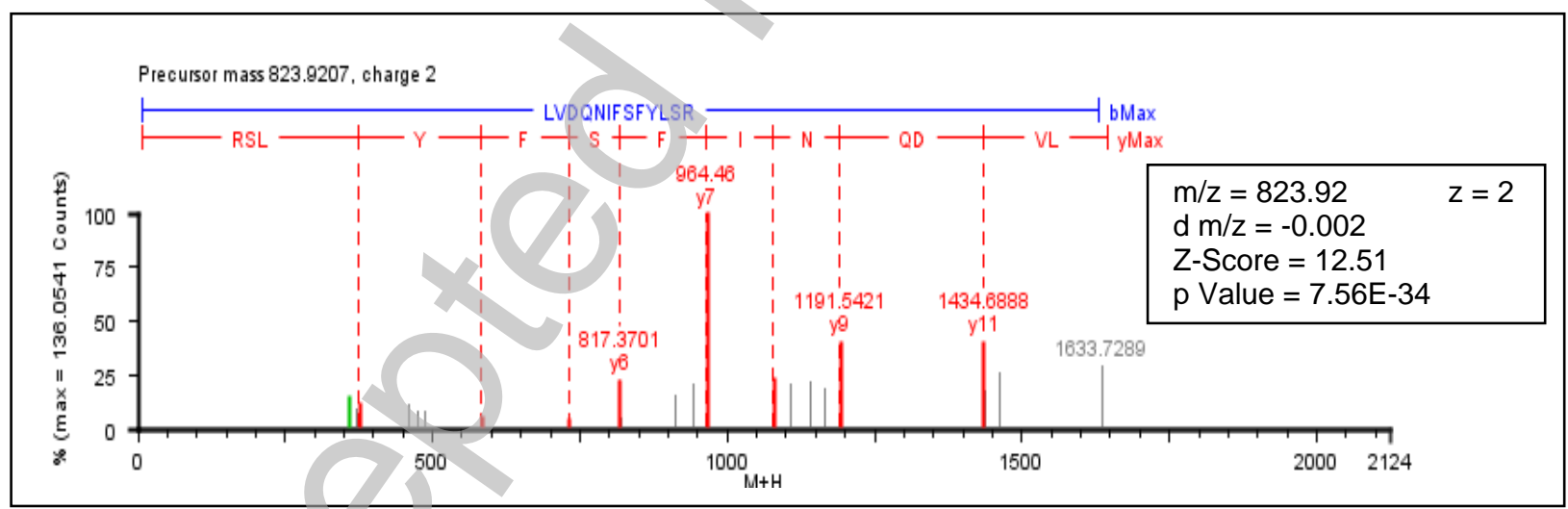




\title{
Figure 7.
}

\begin{abstract}
132 DGILGMAYPRISVNNVLPVFDNLMQQKLVDQNIFSFYLSRDPDAQPGGELMLGGT 186 CD human 194 DGILGMGYPHISVNNVLPVFDNLMQQKLVDKNIFSFYLNRDPEGQPGGELMLGGT 248 CD mouse 191 DGILGMGYPFISVNKVLPVFDNLMKQKLVEKNIFSFYLNRDPTGQPGGELMLGGT 245 CD rat

194 DGILGLGYPSLAVGGVTPVFDNMMAQNLVDLPMFSVYMSSNPEGGAGSELIFGGY 250 CE human 181 DGILGLGYPSLAAGGVTPVFDNMMAQNLVALPMFSVYLSSDPQGGSGSELTFGGY $237 \mathrm{CE}$ mouse 182 DGILGLGYPSLAVGGVTPVFDNMMAQNLVALPMFSVYLSSDPQGGSGSELTFGGY 238 CE rat

187 EFDGVGMGFIEQAIGRVTPIFDNIISQGVLKEDVFSFYYNRDSENSQSLGGQIVLG 245 REN human 176 DGILGMAYPSLASEYSIPVFDNMMNRHLVAQDLFSVYMDRNGQESMLTLGAIDPSY 233 CHY bovine 177 DGILGLAYPSISASGATPVFDNLWDQGLVSQDLFSVYLSSNDSGSWLLGGIDSSY 233 PEP porcine
\end{abstract}

